UNIVERSIDADE DE BRASÍLIA

FUP - Faculdade UnB Campus Planaltina

\title{
A IMPORTÂNCIA DA GESTÃO DA QUALIDADE NA CEASA DO DISTRITO FEDERAL
}

José Joardvan Camelo de Freitas

Brasília - DF

2011 


\section{A IMPORTÂNCIA DA GESTÃO DAQUALIDADE NA CEASA DO DISTRITO FEDERAL}

Relatório de Estágio de Graduação em Gestão do Agronegócio, apresentado à Faculdade UnB Campus Planaltina, como exigência para a conclusão da disciplina de estágio supervisionado. Orientador: Mauro Eduardo Del Grossi

$$
\text { Brasília - DF }
$$




\section{SUMÁRIO}

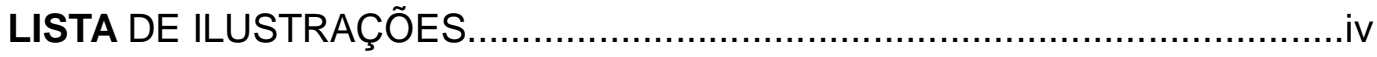

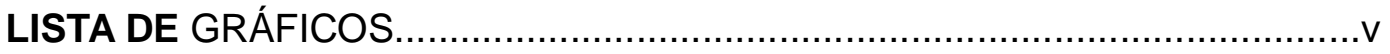

LISTA DE ABREVIATURAS E SIGLAS ...............................................vi

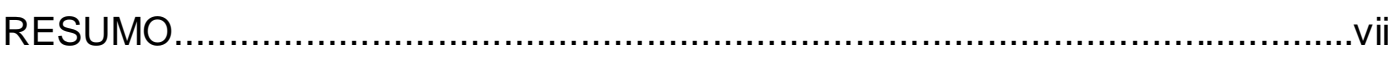

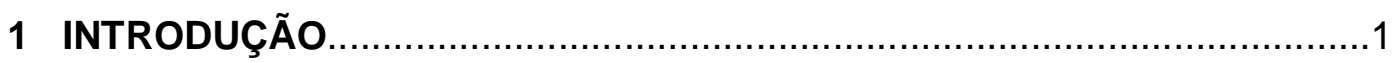

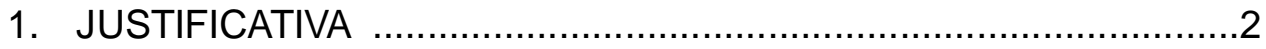

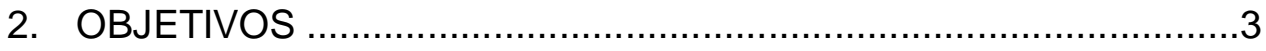

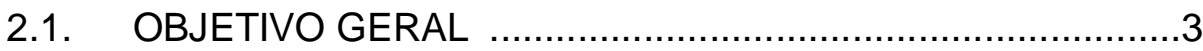

3. OBJETIVOS ESPECÍFIOS .....................................................

4. LOCALIZAÇÃO E ESTRUTURA DA ORGANIZAÇÃO ...................3

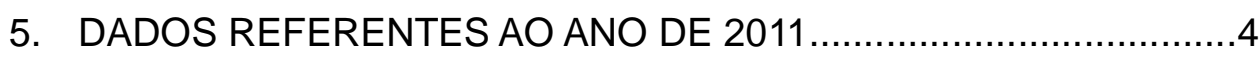

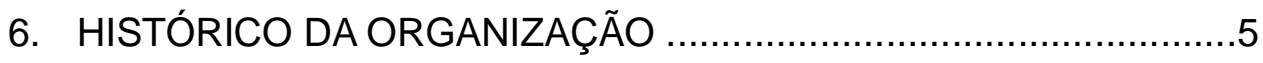

7. ORGANOGRAMA DA ORGANIZAÇÃO .................................. 9

2. REFERENCIAL TEÓRICO....................................................................... 10

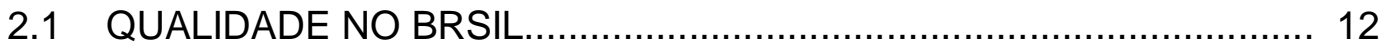

2.2 INDICAÇÕES CENTRADAS NO PROJETO.......................................11

2.3 INDICADORES CENTRADA NO VALOR PARA O CLIENTE..................14

2.4 INDICADORES CENTRADOS NO PROCESSO ................................15

2.5 INDICADORES CENTRADOS NOS RESULTADOS .............................15

2.6 INDICADORES CENTRADOS NA RESPONSABILIDADE SOCIAL......16

2.7 INDICADORES CENTRADOS NOS RECURSOS HUMANOS..............16

3 METODOLOGIA..........................................................................

3.1 ATIVIDADES DESENVOLVIDAS NO ESTÁGIO..............................18

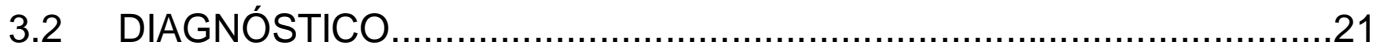

4 ANÁLISE E INTERPRETAÇÃO DOS DADOS .............................28

4.1 ENTREVISTA COM OS PERMISSIONÁRIOS ............................... 28

4.2 ENTREVISTA COM OS PRODUTORES ..................................... 28

4.3 ENTREVISTA COM OS COLABORADORES ............................. 29

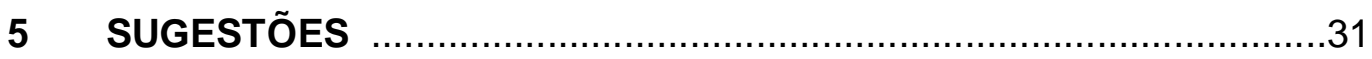




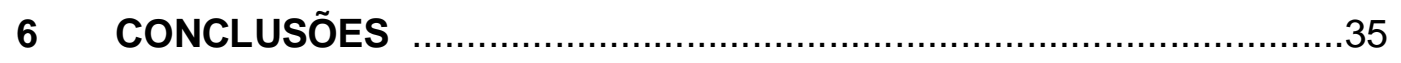

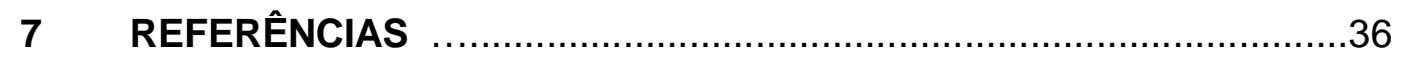

ANEXO A TERMO DE PERMISSÃO REMUNERADA DE USO

ANEXO B DECLARAÇÃO DE ATIVIDADE RURAL

ANEXO C CONTRATO DE PARCERIA

ANEXO D ROMANEIO DE ENTRADA

ANEXO E BOLETIM INFORMATIVO DO MERCADO ATACADISTA 


\section{LISTA DE ILUSTRAÇÕES}

FIGURA 1 - ESPAÇO DO PRODUTOR (PEDRA).................................16

FIGURA 2 - LIXO ORGÂNICO JOGADO JUNTO À RAMPA DO BOX........17

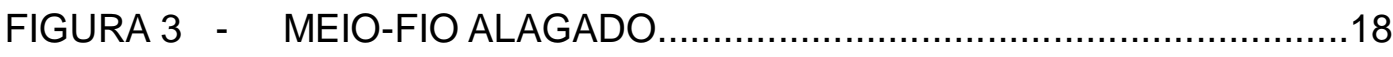

FIGURA 4 - UNIDADE DE SOCORRO MÉDICO.....................................19

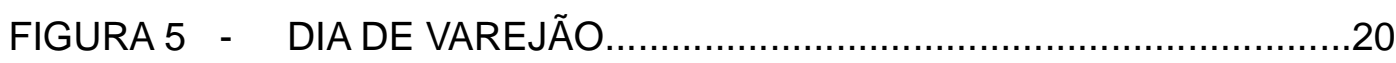

FIGURA 6 - DESCARTE DE LIXO NA ESQUINAE NA RUA ..............................27 


\section{LISTA DEA BREVIATURAS E SIGLAS}

COBAL - COMPANHIA BRASILEIRA DE ALIMENTOS

CONAB - COMPANHIA NACIONAL DE ABASTECIMENTO

CENABRA - CENTRAL DE ABASTECIMENTO DE BRASÍLIA

FPNQ - FUNDAÇÃO PARA O PRÊMIO NACIONAL DA QUALIDADE

EMBRAPA -EMPRESA BRASILEIRA DE PESQUISA AGROPECUÁRIA

SEAPA - SECRETARIA DE AGRICULTURA, PECUÁRIA E ABASTECIMENTO

TPRU - TERMO DE PERMISSÃO REMUNERADA DE USO 


\section{INTRODUÇÃO}

Este estudo tem como objetivo a realização do Estágio Supervisionado do curso de Gestão do Agronegócio, como requisito para a conclusão do curso.

A empresa escolhida para estagiar foi a Centrais de Abastecimento do Distrito Federal/AS, CEASA - DF.

Este trabalho tem como objetivo principal enfatizar a importância da qualidade na gestão do Sistema Ceasa-DF, da produção à comercialização.

Entenda-se que a qualidade, como enfoque deste trabalho, aplica-se a todas as fases do abastecimento de hortigranjeiros, alem de abarcar as condutas padronizadas no manuseio, desde o emprego correto dos defensivos químicos, colheita, acondicionamento, transporte, até a exposição desses produtos nas bancas para a comercialização. Serão tratados os assuntos relativos à limpeza, higienização e sanidade.

Outro aspecto relevante de que trata este trabalho, diz respeito à análise das práticas administrativas desenvolvidas na gestão atual, as medidas levadas a efeito e que estão em fase de andamento, bem como mudanças sugeridas para viabilizar o desenvolvimento das atividades, sejam estas, ligadas ao planejamento das ações gerenciais ou operacionais e a supervisão dos procedimentos padronizados, constantes do regulamento de mercado da Ceasa do Distrito Federal.

No intuito de coletar informações que servissem de base para a confecção deste trabalho, foi feita uma pesquisa com os permissionários, produtores, serventuários e clientes.

As técnicas gerenciais aqui contextualizadas evocam 0 uso sistemático de algumas ferramentas de gestão, referidas aos públicos interno e externo e almejam o alcance dos padrões minimamente estabelecidos pelo movimento da qualidade, através do processo de "melhorias contínuas". 
Sabe-se que, na atualidade, as empresas procuram, cada vez mais, obter os atributos da gestão da qualidade, a fim de que possam manter-se neste mercado crescentemente competitivo.

$\mathrm{Na}$ década de 80, quando surgiram as primeiras aplicações dos conceitos sobre a qualidade e a reengenharia, muitas empresas que implantaram tais modelos de gestão não conseguiram obter sucesso e até abandonaram ou refizeram suas rotinas. Acontece que, não basta implementar um modelo de gestão para garantia de sucesso. É preciso que haja o devido comprometimento de toda a organização, no sentido da promoção de mudanças capazes de criar novos referenciais, mudar culturas, hábitos e rotinas e, se necessário, arrancar vícios para que as mudanças surtam o efeito desejado.

Segundo MOURA (1993, p. 7), "dentre os vários frutos da qualidade em seu conceito moderno, podemos destacar a redescoberta do cliente".

Uma questão que parece simples e que, praticamente todos conhecem a importância do cliente para a qualidade que a empresa oferece. Torna-se bastante complexa a ação de medir a satisfação do cliente. Muitos já se perguntaram: como medir esta abstração intangível chamada satisfação do cliente?

Conforme GONÇALVES (1997, p.75) "várias técnicas de medição podem avaliar a qualidade de processos de negócios, produtos e serviços. Medidas de qualidade geralmente enfocam indicadores objetivos ou concretos".

\section{$1.1 \quad$ JUSTIFICATIVA}

Este trabalho proporciona ao estudante a possibilidade de colocar em prática os ensinamentos acadêmicos da disciplina de Gestão do Agronegócio, em proveito da própria empresa. 


\subsection{OBJETIVO}

\subsubsection{OBJETIVO GERAL}

Realizar uma análise do modelo de gestão da Ceasa - DF, referindoo aos fundamentos do movimento da qualidade, com foco no cliente e no mercado.

\subsection{OBJETIVOS ESPECÍFICOS}

1.3.1 Descrever a situação atual da empresa e sua evolução no campo do abastecimento de hortigranjeiros do Distrito Federal;

1.3.2 Identificar as iniciativas, referidas à gestão da qualidade, empreendias pela atual administração

1.3.3 Buscar a visualização do panorama futuro do abastecimento hortícola do DF, em razão das ações presentes.

\subsection{LOCALIZAÇÃO E ESTRUTURA DA ORGANIZAÇÃO}

A Ceasa - DF é uma empresa de economia mista, integrante do complexo administrativo do Governo do Distrito Federal, dotada de infraestrutura adequada para a comercialização de gêneros alimentícios "in natura", produtos e insumos agropecuários, além de outros serviços de apoio e de pontos comerciais ligados a outras atividades do agronegócio. Sua área de 615.592,52 $\mathrm{m}^{2}$ está distribuída sistematicamente da seguinte forma:

- 08 (oito) pavilhões permanentes destinados a empresas estabelecidas com permissão de uso, para comercialização atacadista de produtos hortigranjeiros, num total de 21.697,05 $\mathrm{m}^{2}$ de área construída;

-01 (um) pavilhão não permanente destinado à comercialização de insumos agropecuários, com área de 20.039,20 m2;

- 01 (um) pavilhão permanente destinado à comercialização atacadista de gêneros oriundos da produção local (hortigranjeiros), com área de $8.682,50 \mathrm{~m} 2$; - 01 (um) pavilhão permanente destinado a serviços de apoio (bancos, farmácias, casa lotérica, restaurante, etc) e sede da administração, com área de $2.850,25 \mathrm{~m}$; 
- 01 (um) posto de abastecimento de combustíveis, com área total de 7.200,00m2;

- 01 (um) hipermercado atacadista (Makro Atacadista), que oferece mais de 20.000 itens, entre alimentos, produtos de higiene e limpeza, confecções, eletrodomésticos e eletrônicos, camping, etc, com área total de $60.000 \mathrm{~m} 2$;

-01 (um) complexo frigorífico, com capacidade de armazenamento para 7.000 toneladas de produtos (arrendado à Friozen), com área total de $40.000 \mathrm{~m} 2$;

- 01 (uma) balança rodoviária com capacidade para pesagem de $62.000 \mathrm{Kg}$;

- 01 (um) silo búfalo (CONAB), com área total de 104.000 m2.

A Ceasa - DF tem como missão o incremento à produtividade no setor de hortigranjeiros do Distrito Federal e a distribuição eficiente de seus produtos, que implica o exercício de suas funções básicas, a saber:

Redução dos custos de comercialização; melhoria das condições de abastecimento; propiciar facilidade para o escoamento da produção agrícola; formar um banco de dados (Boletim Informativo do Mercado Atacadista da Ceasa) que permite o planejamento da produção agrícola e interagir com o Ministério da Agricultura, Pecuária e Abastecimento, na formação de normas de classificação e padronização de hortaliças e frutas.

\subsection{DADOS REFERENTES AO ANO DE 2011}

Área total da Ceasa

Área total urbanizada

Área pavimentada

Área de estacionamento

Número de produtores cadastrados

Número de atacadistas

Total Comercializado ao ano

Movimento financeiro anual (total)
$615.592,52 \mathrm{~m} 2$

$427.000,00 \mathrm{~m} 2$

$150.000,00 \mathrm{~m} 2$

$100.000,00 \mathrm{~m} 2$

500

180

27.000 toneladas

$\mathrm{R} \$ 39$ milhões 
No início da década de 70, quando a comercialização de hortigranjeiros era realizada de modo precário em razão de não existir estruturas adequadas para a realização dos negócios, estes aconteciam nas ruas, nos mercados obsoletos e nas feiras livres, onde não existiam equipamentos disponíveis ao manuseio adequado dos produtos e nem havia padronização ou regulamentação alguma sobre tal atividade. À medida que as grandes cidades cresciam, maior tornava-se essa necessidade. A par disso, o Governo Federal resolveu criar o Sistema Nacional de Abastecimento (SINAC), deixando a Cobal (Companhia Brasileira de Alimentos), encarregada da implantação e da gestão daquele complexo de Centrais de abastecimento, nas capitais e nas maiores cidades do país, isto, por volta do ano de 1970, através da Lei $n^{\circ} 5.691$, de 10 de agosto daquele ano.

A Central de Abastecimento de Brasília (Cenabra), hoje Ceasa-DF, foi a primeira das 14 centrais implantadas pelo programa prioritário do Governo Federal intitulado Modernização de Sistema Nacional de Abastecimento. Inaugurada em setembro de 1972. A Cenabra, na época, começou a funcionar com parte das comemorações do Sesquicentenário da Independência da República.

A Central de Brasília passou a ser administrada por uma Sociedade de Economia Mista, constituída para esse fim, a Central de Abastecimento de Brasília - SA - Cenabra - cujos principais acionistas eram a Companhia Brasileira de Alimentos (Cobal) e o Governo do distrito Federal, sendo o restante do investimento financiado pelo BNDES, em 16 anos, com 3 anos de carência.

Para a execução do Plano Nacional de Abastecimento, o Governo criou o Grupo Executivo de Modernização do Sistema de Abastecimento GEMAB, com a incumbência de tomar as devidas providências para a implantação do programa de construção das Ceasas e Mercados Terminais, bem como de outras medidas necessárias à modernização do abastecimento na esfera federal.

Implantado com êxito total, o modelo brasileiro de centrais de abastecimento, orientado nas experiências da França e, especialmente, da 
Espanha, experimentou mudanças radicais e incorporou novos métodos e avanços tecnológicos, o que o levou a ser adotado como referência para outros países em desenvolvimento. Assim, a FAO, o Banco Mundial e outros organismos internacionais passaram a recomendar o sistema brasileiro. Ironicamente, todo esse desenvolvimento, fruto de um trabalho profícuo da Cobal e do Ministério da Agricultura, foi jogado por terra ao final de 1986, quando o Governo Federal resolveu abdicar do sistema e privatizou-o, entregando-o aos Estados e Municípios, o que levou à falência generalizada das Ceasas, que perderam a unicidade da política de abastecimento e a coordenação a nível nacional. É verdade que para algumas delas, como a de Brasília, que já começou alocada ao GDF, não houve maiores percalços com a privatização.

A primeira Ceasa do DF começou no Núcleo Bandeirante e, de 1971. De lá para cá, a empresa evoluiu, cresceu e, naturalmente, modernizou-se, mesmo porque a oferta de hortaliças e outros gêneros alimentícios aumentou de forma progressiva no mercado de Brasília e região adjacente. A população da capital triplicou-se; foram criadas várias cidades ao redor de Brasília, de modo que a movimentação de produtos hortigranjeiros foi aumentando junto com o Distrito Federal. A CEASA - DF estabeleceu-se em definitivo no Setor de Indústria e Abastecimento (SIA), do trecho 05 ao 10, numa extensa área de domínio.

Apesar das mudanças ocorridas desde o tempo em que a empresa estava sediada no Núcleo Bandeirantes, alguns atacadistas que compunham sua estrutura inicial, ainda continuam fazendo parte da atual. Alguns permanecem com o mesmo nome de batismo e podem comemorar, junto com a Ceasa - DF, os seus proveitosos 40 anos de atuação no mercado de hortigranjeiros de Brasília e regiões vizinhas. Há também outros que iniciaram pioneiramente naquele tempo e, por motivos diversos, mudaram de nome e/ou de dono, mais continuam fazendo parte desta entidade-modelo no abastecimento do DF e Região. Para que se possa confirmar, segue alguns nomes de empresas pioneiras no sistema Ceasa- DF:

- $\quad$ Comercial de Frutas Mendes; 
- $\quad$ Ovos Beatriz (antiga Kuo Kato);

- $\quad$ Bradisba (Brasília Distribuidora de Batatas);

- $\quad$ Fortaleza (antiga Zé Vieira);

- Brasília Frutas;

- $\quad$ Ki Fruti;

- $\quad$ Alexaves (ovos);

- $\quad$ Toca Distribuidora de Alimentos (antiga M. Sato);

- $\quad$ ADF Distribuidora de Alimentos (antiga cooperativa Cotia);

- $\quad$ Tigrão (antiga Salomé);

- $\quad$ Brasília Distribuidora de Frutas.

É certo que existem muitas outras empresas que mudaram de nome, pois, a maioria delas são do modelo de gestão familiar, entretanto ainda estão atuando na Ceasa - DF; dentre os quais se encontram: José Agrício Barbosa, José Rufino, Augustinho Izaque, Ovos aprovo, João Félix Sobrinho, Geraldo Mandu, Leão dos cocos, Jamelão, Argemiro Juvino, Roberto Banana e Raimundo Avelar, entre outros, que são detentores dos boxes, estabelecidos para realizarem o comércio atacadista, em oito dos onze pavilhões permanentes, cujo contrato tem como instrumento legal de autorização de uso, o "Termo de Permissão Remunerada de Uso" (TRPU).

Durante o tempo decorrido entre sua fundação, nos anos 70 , até os dias de hoje, a Ceasa - DF tem acompanhado o desenvolvimento de Brasília e da região circunvizinha. Naturalmente, seu crescimento deu-se de modo articulado com o crescimento da capital e, para isso acontecer, a Ceasa teve sempre a preocupação de incentivar a produção e a distribuição hortícola de toda a região circunvizinha, através dos programas de apoio aos produtores e promoção de campanhas de distribuição de hortaliças às comunidades de menor poder aquisitivo.

O exemplo mais festejado disso é o Mercado Volante, mais conhecido por PAI (programa de abastecimento integrado), em que seis ônibus percorrem as cidades satélites, levando cerca de 30 produtos diferentes a preço único e bem abaixo dos praticados nas feiras. $\mathrm{Na}$ atual administração, além de 
continuar em vigor o programa de alimentação integrada, foram criados os programas Desperdício Zero, o Banco de Alimentos e o Sacola Cheia, iniciativas estas que envolvem a parceria dos produtores e dos permissionários dos boxes.

Com o objetivo de agregar valor aos gêneros destinados à comercialização na própria Ceasa, esta criou um programa de assistência aos produtores de hortaliças, no sentido de orientá-los quanto aos cuidados que devem ser dispensados aos produtos durante a colheita, o acondicionamento, armazenamento e transporte destes. Para que isto fosse possível, a Ceasa DF conta com o apoio da EMBRAPA HORTALIÇAS e da EMATER - DF, que contribuem de forma decisiva para o cumprimento da missão da Ceasa-DF, de incrementar a produção, viabilizar a distribuição e agregar valor aos produtos hortigranjeiros comercializados no Distrito Federal e Região circunvizinhos

Na gestão atual estão sendo realizadas as necessárias instâncias junto ao Governo do Distrito Federal, para a ampliação da pedra do produtor, na Ceasa - DF e, também, da construção de mais outra pedra, na cidade de Planaltina. Todas essas iniciativas fazem parte do novo modelo de gestão referido à qualidade, adotado pela atual administração. 


\subsection{ORGANOGRAMA DA CEASA DO DISTRITO FEDERAL}

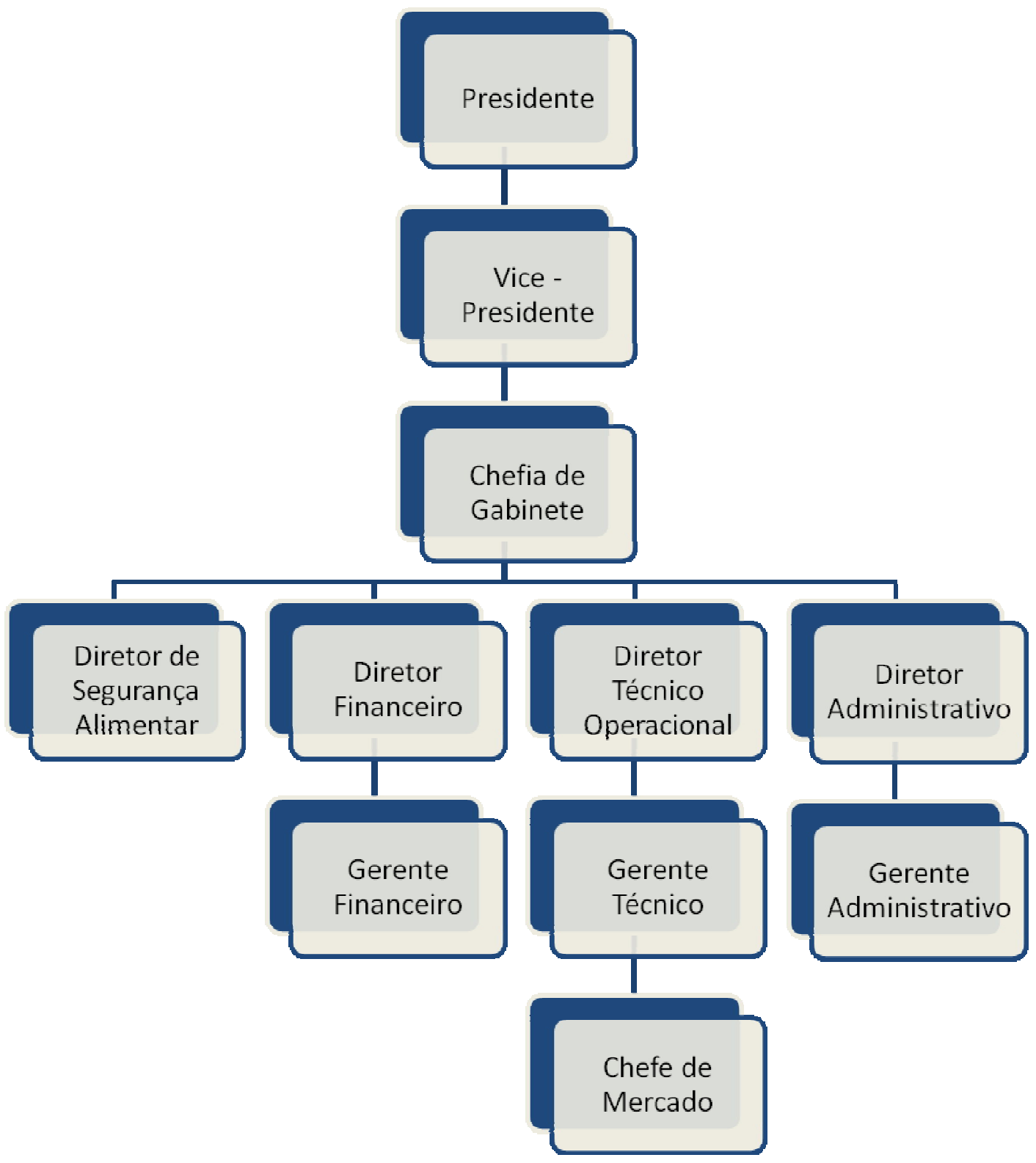




\section{REFERENCIAL TEÓRICO}

No dicionário Aurélio (FERREIRA, 1999, P. 1675), diz que:

Qualidade (do latim qualitatem) e propriedade, atributo ou condição Das coisas ou das pessoas capazes de distingui-las das outras ou de Ihes determinar a natureza. Numa escala de valores, qualidade que permite avaliar e, consequentemente, aprovar, aceitar ou recusar qualquer coisa. Dote, dom, virtude, condição, posição, função.

Para Falconi, "um produto ou serviço de qualidade é aquele que atende perfeitamente, de forma confiável, de forma acessível, deforma segura e no tempo certo às necessidades do cliente".

De qualquer modo como for apresentada, a definição de qualidade dependerá do referencial, como coloca Deming (DEMING, 1990, p. 125):

O que é qualidade? A qualidade só pode ser definida em termos de quem avalia. Quem é o juiz da qualidade? $\mathrm{Na}$ opinião do operário, ele produz a qualidade se puder se orgulhar do seu trabalho. Baixa qualidade para ele significa perda de negócios e, até, do seu emprego. Alta qualidade, pensa ele, manterá a empresa no ramo. 
Quadro 1: Classificação de itens importantes ou não nas Definições de Qualidade

Características do produto que atendam

Ausência de deficiências

as necessidades dos clientes

Qualidade superior possibilita que as Qualidade superior possibilita que as empresas: empresas

- Aumentam a satisfação dos clientes

- Reduzam os índices de erros

- Tornem os produtos vendáveis

- Reduzam a repetição de trabalhos e - Aumentem sua participação do mercado desperdícios

- Obtenham receitas de vendas

- Reduzam as falhas no uso e os custos de garantia

- Garantam preços melhores

- Reduzam a insatisfação dos clientes

- O maior efeito sobre as vendas

- Reduzam o prazo para o lançamento

- Normalmente, a qualidade superior custa mais

de novos produtos no mercado

- Aumentem rendimentos e capacidade

- Melhorem o desempenho de entregas

- O maior efeito e sobre custos

- Normalmente, a qualidade superior custa menos

Fonte: J.M. Juran - qualidade desde o projeto,1992, p. 10

Isto é verdade, tanto para as empresas de serviço, quanto para as de produção de bens. Qualidade, para o administrador de fábrica, significa produzir a quantidade planejada e atender às especificações. Sua função é também, saiba ele, ou não, o constante aperfeiçoamento dos processos e a constante melhoria de sua liderança. 
Para ratificar a colocação de Deming, segue a idéia de J. M. Juran (1992, p. 10): "Não existe a possibilidade de adoção de definições universais, a não ser que seja desenvolvido um glossário patrocinado por um organismo reconhecido ou de padronização"

Após esta caminhada, a qualidade nos dias de hoje faz parte do cotidiano das organizações e agora está mais relacionada às necessidades e aos desejos dos clientes, sejam oriundos de mercado de bens ou serviços.

\subsection{QUALIDADE NO BRASIL}

O desenvolvimento da qualidade surgiu no Brasil a partir dos anos 50 , com a criação das indústrias de produtos de base. "A preocupação com a segurança pessoal e operacional, através da qualidade dos equipamentos, surgiu nas indústrias siderúrgica, de petróleo e petroquímica". (MARTINS, 2003, p. 21)

Nos anos 80, o Governo iniciou a implementação de diversos programas de qualidade, os quais tinham o objetivo de (MARTINS, 2003, p. 22): "Dar condições às empresas brasileiras, privadas e públicas de buscarem a competitividade como uma estratégia de desenvolvimento, visando à capacitação tecnológica e à gestão empresarial inovadora, baseando-se na aplicação de práticas voltadas para a qualidade e a produtividade".

São diversos os programas voltados ao desenvolvimento científico e tecnológico e aumento dos financiamentos à pesquisa, visando a qualidade e a produtividade e baixos custos; dos quais destaca-se O Prêmio Nacional da Qualidade. Atribuído anualmente às empresas brasileiras que se destacam pela qualidade de seus produtos e serviços e visa promover amplo entendimento dos requisitos para alcançar a excelência do desempenho e, portanto, a melhoria da competitividade, bem como, a troca de informações sobre métodos e sistemas de gestão que alcançaram sucesso e sobre os benefícios decorrentes da utilização dessas estratégias.

Dentre seus critérios de avaliação destaca-se o "Foco no Cliente e no Mercado". Este critério é o ponto crucial da avaliação no exame de como a organização busca o atendimento das aspirações do cliente e do mercado. As empresas são julgadas em relação ao seu conhecimento sobre o cliente e 0 
mercado; acessibilidade e gestão das reclamações e seus métodos para determinar ao grau de satisfação dos clientes.

A qualidade centrada no cliente é, pois, um conceito estratégico, voltado para a sua retenção e a conquista de novas fatias de mercado, sensibilidade constante em relação às novas exigências dos clientes e do mercado e a identificação dos fatores que promovam a retenção e a satisfação dos clientes.

Exige, também, sensibilidade quanto ao desenvolvimento de tecnologia e às ofertas dos concorrentes, resposta rápida e flexível aos requisitos dos clientes e do mercado.

A qualidade centrada no cliente significa muito mais do que simplesmente a redução e erros e defeitos, ou do mero atendimento às especificações ou da redução de reclamações. Evidentemente, a redução de erros e defeitos e eliminação das causas de insatisfação contribuem significativamente para a percepção da qualidade pelo cliente e são, deste modo, partes importantes desse processo. Além disso, o êxito obtido pela organização ao se recuperar de erros e defeitos, corrigindo-os, evitando sua repetição e compensando o cliente pelas eventuais falhas, é crucial para 0 relacionamento com os clientes e sua retenção. (FPNP, 1997:6).

Com estas considerações, conclui-se que, para conhecer de maneira contínua o cliente e o marcado, são necessárias amplas variedades de estratégias. Reportando-se ao FPNQ (1997), já em outras oportunidades referenciadas, vê-se ali alguns exemplos de enfoques que podem fazer parte das estratégias para ouvir e aprender com o cliente. Assunto também abordado por Phillps, enfatizando que o cliente, quando ouvido, é muito mais do que do que apenas um cliente. $O$ seu relacionamento vai além da caixa registradora; ele é,também, um grande entusiasta pelo desenvolvimento e sucesso da organização. Alguns exemplos de enfoque apresentados pela FNPQ (1997) e que se procurou manter neste trabalho, estão abaixo enumerados:

2. Construção do relacionamento, incluindo uma integração mais estreita com os clientes; 
3. Rapidez na inovação e nos ensaios do produto no campo para melhorar a ligação entre pesquisa, desenvolvimento e mercado;

4. Monitoramento rígido de fatores tecnológicos, competitivos, sociais, ambientais, econômicos e demográficos que possam dar suporte às preferências, às expectativas e aos requisitos dos clientes ou oferecer alternativas;

5. Grupos de foco com clientes exigentes e de vanguarda;

6. Treinamento do pessoal da linha de frente em métodos para ouvir os clientes;

7. Utilização de incidentes críticos, como reclamações, para entender os principais atributos de serviço, do ponto de vista dos clientes e do pessoal da linha de frente;

8. Entrevistas com os clientes perdidos para determinar os critérios utilizados em suas decisões de compra;

9. Análise dos maiores fatores de influência sobre os principais clientes.

\section{2 INDICADORES CENTRADOS NO PROJETO}

Segundo PALADINI (1995, p. 48), "denomina-se qualidade de projeto a análise que se faz do produto, em termos de qualidade, a partir da estruturação de seu projeto".

A qualidade de projeto determina o grau de acerto das decisões tomadas sobre o produto a ser lançado. A essência da qualidade de projeto é a segmentação do mercado, ou seja, em que mercado o produto vai atuar, que, por sua vez, é realizada através de pesquisa junto ao cliente.

\section{3 INDICADORES CENTRADOS NO VALOR PARA O CLIENTE}

DEMING (1986) apresentou os quatro caminhos para uma organização melhorar a sua qualidade: inovar ou melhorar os seus processos e inovar ou melhorar os seus produtos. Os processos organizacionais transformam os recursos capitais, tecnologia, matérias-primas e trabalho em produtos que possuem valor sob a percepção do cliente. 


\section{4 INDICADORES CENTRADOS NO PROCESSO}

Estes indicadores baseiam-se no conjunto de atividades que compõem um processo produtivo, que leva à completa satisfação do cliente. Envolve o conceito de melhoria contínua, buscando a eliminação de defeitos refugos e retrabalho, a redução de erros, minimização dos custos de produção e eliminação de esforços inúteis.

Foi dentro desse conceito de melhoria contínua, que surgiu a Just-intime, que agiliza os fluxos de produção, reduzindo e otimizando os estoques. É, hoje, utilizado pelas indústrias do mundo inteiro.

\section{5 INDICADORES CENTRAOS NOS RESULTADOS}

A qualidade centrada nos resultados é a qualidade que deve satisfazer a todos os envolvidos no processo, de uma forma equilibrada. A organização deve satisfazer seus clientes internos e externos, mas também satisfazer seus acionistas ou proprietários.

Segundo BROWN (1995, p. 75), "medidas a prazo mais longo, tais como, satisfação dos funcionários e desenvolvimento de novos produtos, devem ser parte dos dados de resultados globais da organização".

As empresas devem utilizar esses indicadores da qualidade para comunicar as prioridades de curto e de longo prazos, monitorar o real desempenho e dispor, de forma ordenada, do apoio para a melhoria da qualidade. 


\section{6 INDICADORES CENTRADOS NA RESPONSABILIDADE SOCIAL}

Segundo MOURA (1993, p. 31), "sob o enfoque da qualidade, a responsabilidade social da empresa é a resultante do atendimento das expectativas e requerimentos da comunidade". A empresa deverá tomar conhecimento destes requerimentos, traçar um plano de atendimento, conforme seus recursos disponíveis, que demonstre bom desempenho do ponto de vista da ética, da saúde, da segurança pública e do meio-ambiente.

\section{2. $7 \quad$ INDICADORES CENTRADOS NOS RECURSOS HUMANOS}

A produção da qualidade depende fundamentalmente dos recursos humanos. Mesmo com o grande desenvolvimento tecnológico da automação, não se encontrou forma de total substituição do ser humano. É ele que exige o maior investimento que pode também determinar o maior retorno ou maior perda, em termos de contribuição para a produção da qualidade. Também é ele que traz, transmite e gera as informações.

Neste sentido, indicadores centrados nos recursos humanos devem considerar, necessariamente, o envolvimento, participação e desenvolvimento das pessoas na organização. Com base nestes pontos enfatizados, os indicadores da qualidade podem ser utilizados como fator de motivação dos recursos humanos, a partir do estabelecimento de metas de melhoria contínua desses próprios indicadores e da definição de recompensas por desempenho. 


\section{METODOLOGIA}

Este trabalho trata-se de um estudo de caso que, com a finalidade de verificar a eficácia, a eficiência e a efetividade das práticas gerenciais e operacionais em curso, bem como o grau de acatamento das diretrizes vigentes, pelos permissionários e demais usuários do sistema Ceasa/DF, assim como dos resultados auferidos em termos de satisfação da população do Distrito Federal.

Foi realizada uma pesquisa qualitativa, pela coleta de dados primários, obtidos pela observação direta, pelas entrevistas com os usuários, serventuários e público em geral e pela coleta de dados secundários, extraídos dos relatórios e banco de dados do entreposto de comercialização.

Em levantamentos o objetivo é obter informações sobre uma população. São apropriados para pesquisas - diagnóstico. Pesquisas de caráter descritivo não procuram explicar alguma coisa ou mostrar relações causais, como as pesquisas de caráter experimental. Censos, levantamentos de opinião pública ou pesquisa de predição. Pesquisas descritivas não respondem bem ao por quê, embora possam associar certos resultados a grupos de respondentes. Levantamentos de atitudes dentro das organizações são outro exemplo de pesquisa descritiva muito utilizada. Enquanto na pesquisa de mercado trabalha-se com a imagem; nos levantamentos de atitudes geralmente trabalha-se com toda a população. ROESH (1996, p. 129).

Esta análise reflexiva conduz a uma tentativa de aplicação desses conceitos e, para isso, faz-se necessário avaliar se as propostas realizam-se no dia a dia da organização e, como instrumento de aferição, utiliza-se o questionário, para medir o grau de satisfação com os produtos e serviços que Ihe são oferecidos.

Na pesquisa, junto com permissionários, colaboradores e clientes, os dados foram levantados através de entrevistas.

As propostas contidas neste trabalho abrangem adaptações a produtos e serviços oferecidos aos permissionários e aos por eles oferecidos. 
Nos casos em que existe alinhamento das condutas com a reflexão teórica sobre "Gestão da Qualidade", sugere-se um treinamento com os clientes internos, visando criar hábitos proveitosos ao cotidiano da unidade e o conseqüente desfecho exitoso das iniciativas gerenciais.

\subsection{ATIVIDADES DESENVOLVIDAS NO ESTÁGIO}

O período compreendido entre 03 e 15 de outubro de 2011, destinou-se aos acertos e tratativas com o Dr. Jorge Cavadas, gerente técnico, que aceitou de imediato ser o supervisor e ao encaminhamento da proposta ao Presidente da instituição, Dr. Júlio Menegotto.

Este período serviu, também, para conhecimento das pessoas e da rotina de trabalho do entreposto de comercialização, onde, em seguida deu-se o início dos trabalhos, começando pelos conhecimentos relativos à documentação e as tarefas de rotina.

Tendo já presenciado a movimentação no mercado do produtor, que tem por nome popular "pedra do produtor", pude verificar que, de segunda a sábado as atividades mudam conforme a modalidade de negócio a ser desenvolvida, ou seja, nas segundas e quintas, a feira é de atacado (atacadão), em que os produtores, os fornecedores e atacadistas desenvolvem uma feira na modalidade de comércio atacadista, enquanto que, aos sábados, a feira é de varejo (varejão), em que as famílias, tradicionalmente, comparecem para fazerem suas compras semanais de hortaliças e demais gêneros alimentícios.

Aos serventuários lotados no entreposto de comercialização cabe a completa verificação da comercialização, tanto no aspecto da legalidade das transações, como no tocante ao correto uso dos espaços alocados aos permissionários, que se obrigam a respeitar a demarcação exata dos lotes (pedras) que a Ceasa outorgou-Ihes.

Essas tarefas envolvem a conferência das notas fiscais e romaneios de entrada, quando da realização de verificações no portal de entrada da unidade, quase sempre no intervalo de 22:00h do dia anterior, até as 07:00h do dia seguinte. 
No cotidiano do entreposto, os funcionários são constantemente solicitados a resolver conflitos referentes ao abuso no uso de espaço ou transferência de domínio entre permissionários, sem a devida autorização do Chefe de Mercado ou dos Orientadores de Mercado, que com ele trabalham e comungam responsabilidades. Por vezes, faz-se necessária a intervenção dos agentes para a retirada, do espaço interno, de cargas trazidas por comerciantes, que sem o devido cadastro pela Ceasa-DF, tentam negociá-las, infringindo as regras da concorrência a que devem estar sujeitos os permissionários.

$\mathrm{Na}$ rotina de trabalho do entreposto, à exceção dos domingos, o estagiário atua nas atividades de supervisão e orientação de mercado, junto com o chefe de mercado, Sr. Edmundo e os orientadores Professor Ismar, Sr. Marcos, Sr. Felipe e Sr. Hélio, como observador e depois em efetivo exercício. $\mathrm{O}$ desempenho das tarefas de entreposto desenvolve-se em observância à determinação e à orientação da Gerência Técnica.

Paralelamente às atividades do entreposto, observa-se e as atividades de carga e descarga nos boxes, do recebimento e do descarte dos gêneros alimentícios, que, por vezes, faz-se no pátio, junto às rampas dos boxes ou nas áreas comuns (estacionamentos e vias públicas), revelando um completo alheamento às normas de sanidade e de higiene operacional por parte de alguns permissionários e/ou de seus serventuários ou por conta da omissão daqueles em relação às viciadas práticas operacionais destes.

Ainda com relação à observação dos aspectos deficitários, tanto no que se refere às práticas operacionais nos boxes e adjacências, quanto no espaço da "pedra do produtor", quando da realização das feiras de atacado, observa-se um acúmulo de resíduos sólidos, sobretudo folhagem, frutas e verduras no chão, mesmo quando as operações de compra e venda estão em pleno andamento. Este cenário torna-se mais notável aos sábados, quando da realização das feiras do varejão, onde as famílias comparecem para fazer suas compras semanais, muitas vezes pelo prazer de ver o lay out (arrumação das bancas), a variedade de produtos e de ser a própria feira um ponto de encontro ou mesmo um ponto turístico. 
$\mathrm{Na}$ continuação das atividades cotidianas, não somente adstritas ao entreposto, verifica-se o problema da segurança, a questão da carência de reforma na estrutura dos espaços de comercialização e dos estacionamentos, assim como da carência de assistência de uma unidade de saúde e de outros aspectos ligados à gestão referida aos pressupostos da qualidade, pelo uso das ferramentas de gestão, a exemplo da Re-engenharia de Processo e Benkmarking. 


\subsection{DIAGNÓSTICO}

Em razão dos fatos observados e já relatados no rol das atividades desenvolvidas no estágio, conclui-se que temos atualmente os seguintes fatores limitantes capacidade operacional da Ceasa-DF

A Ceasa do Distrito Federal necessita de reformas na sua estrutura, em virtude de que, à medida que a população cresce no DF, assim como em outras cidades grandes, há um correspondente aumento na produção de gêneros alimentícios, para atender a demanda de consumo desta população crescente $e$, por conseguinte, os espaços destinados à comercialização daqueles produtos terão que ser ampliados. Na verdade, até aqui tem havido uma acomodação ou uma adaptação estrutural para atender aos produtores que, cada vez mais, necessitam de espaço para movimentar cargas e armazenar seus produtos

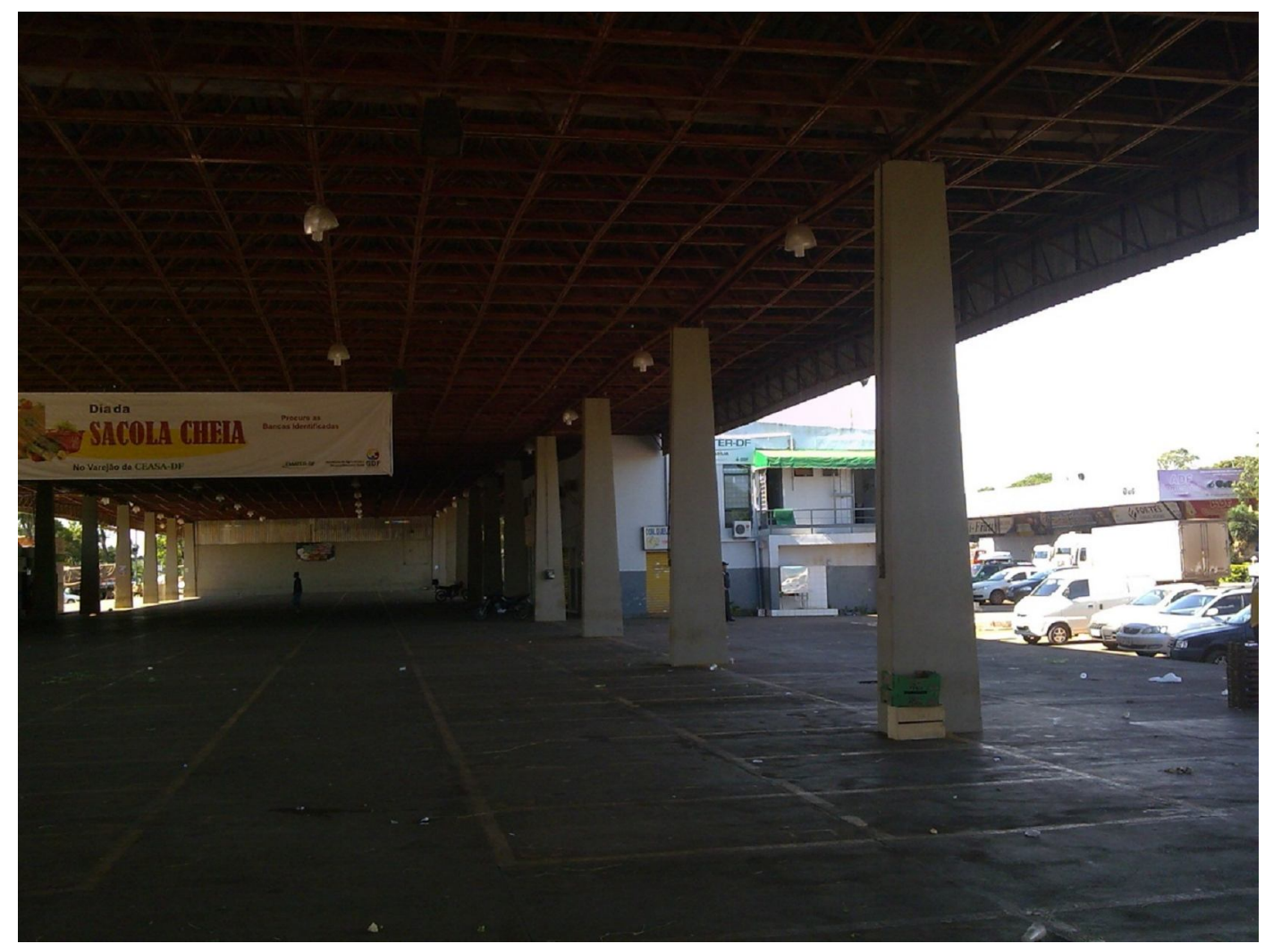

Figura 1. ESPAÇO DO PRODUTOR (PEDRA) 
Nota-se, por vezes, que há relutância, da parte de alguns permissionários, em cumprir as normas contidas no Regulamento de Mercado, que diz expressamente, em seu artigo $9^{\circ}$, que é da responsabilidade do permissionário do Box manter limpas as áreas de carga e descarga de mercadorias e os espaços próximos à rampa, colocando o lixo em sacos plásticos, para que a equipe da limpeza faça a coleta. Verifica-se, à primeira vista, que muitos jogam lixo orgânico na rua mesma, ao lado da rampa ou debaixo desta, próxima ao respectivo Box;

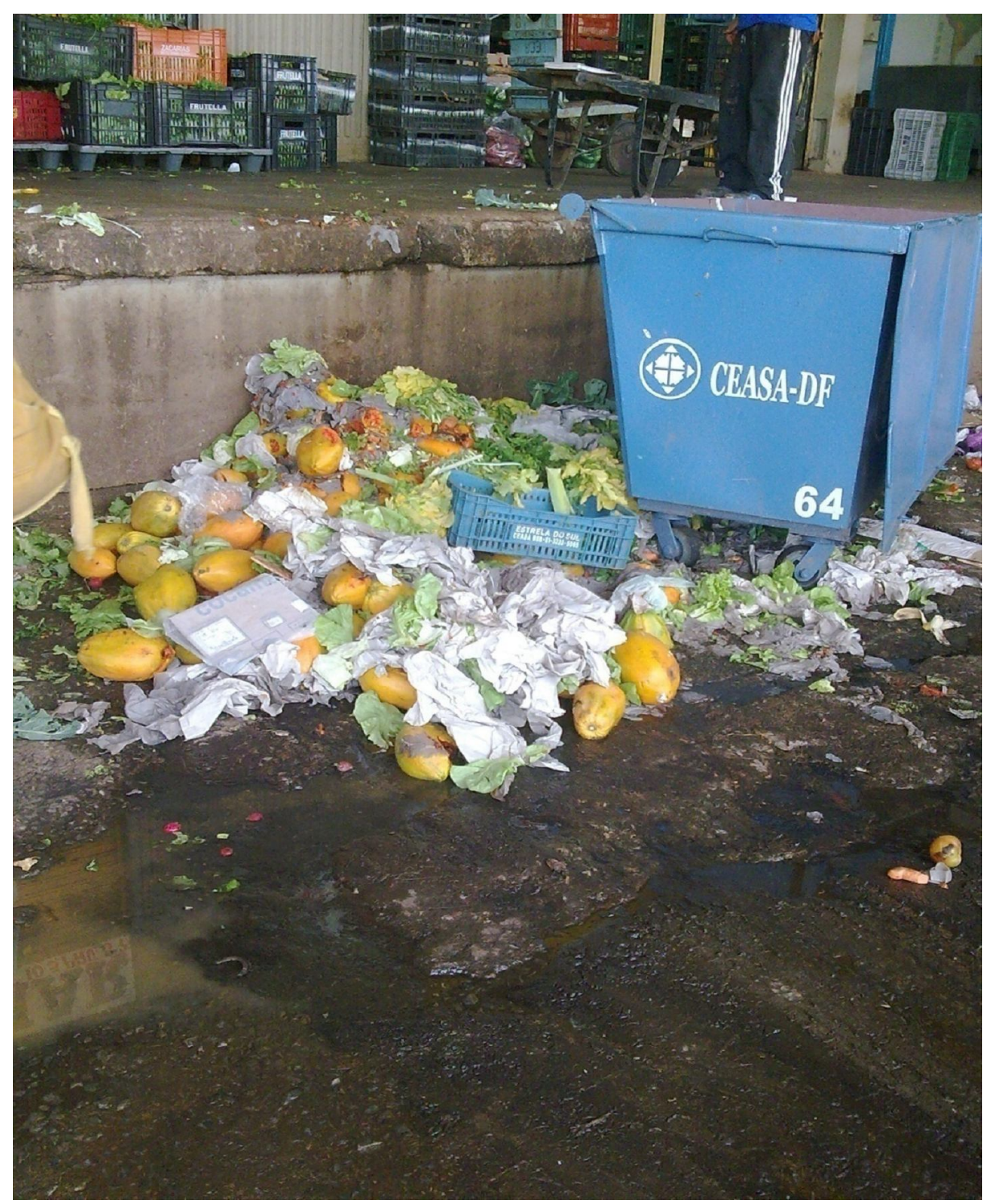

Figura 2. LIXO ORGÂNICO JOGADO JUNTO À RAMPA DO BOX 
Outro problema, de certa gravidade, refere-se ao acúmulo permanente de água suja nas áreas comuns (ao meio-fio das esquinas) e nos pátios das áreas de carga e descarga dos boxes, assim como ao redor dos pavilhões, onde a presença de frutas estragadas, no chão, é constante, propiciando à proliferação de ratos e outros vetores urbanos;

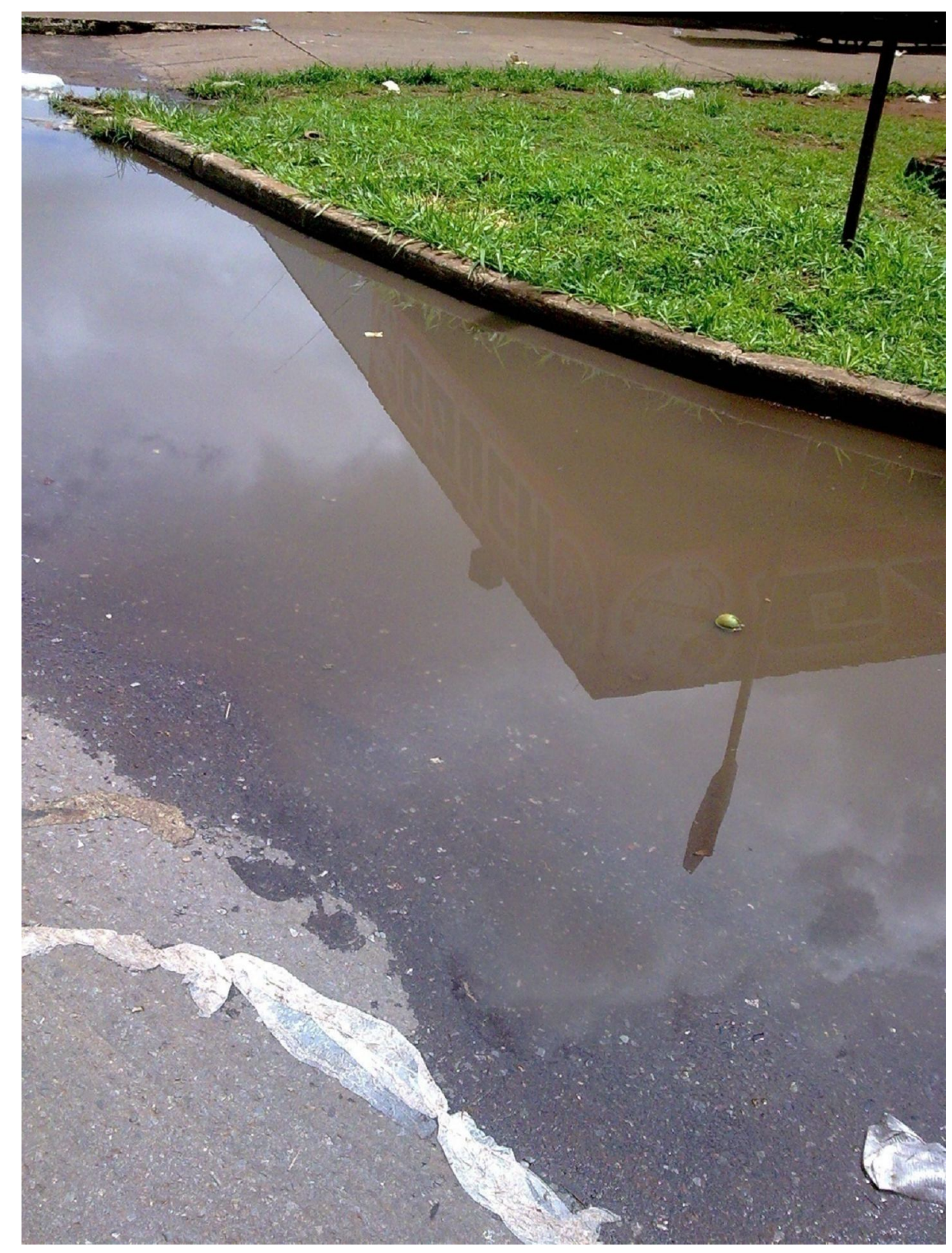

Figura 3. MEIO-FIO ALAGADO

Nos dias das feiras de atacado, ou seja, nas segundas e quintas feiras, a Ceasa abriga em suas instalações a quantia aproximada de 5.000 pessoas e, aos sábados, durante a feira de varejo, circulam por lá mais ou menos 
8.000. Isto já seria o suficiente para que existisse uma Unidade Permanente de Saúde Pública (posto de saúde) no local. Mas se isto não for possível, é necessário que haja, ao menos, a presença de uma Unidade Móvel de Socorro de Urgência (ambulância tripulada), nestes dias de maior movimento;

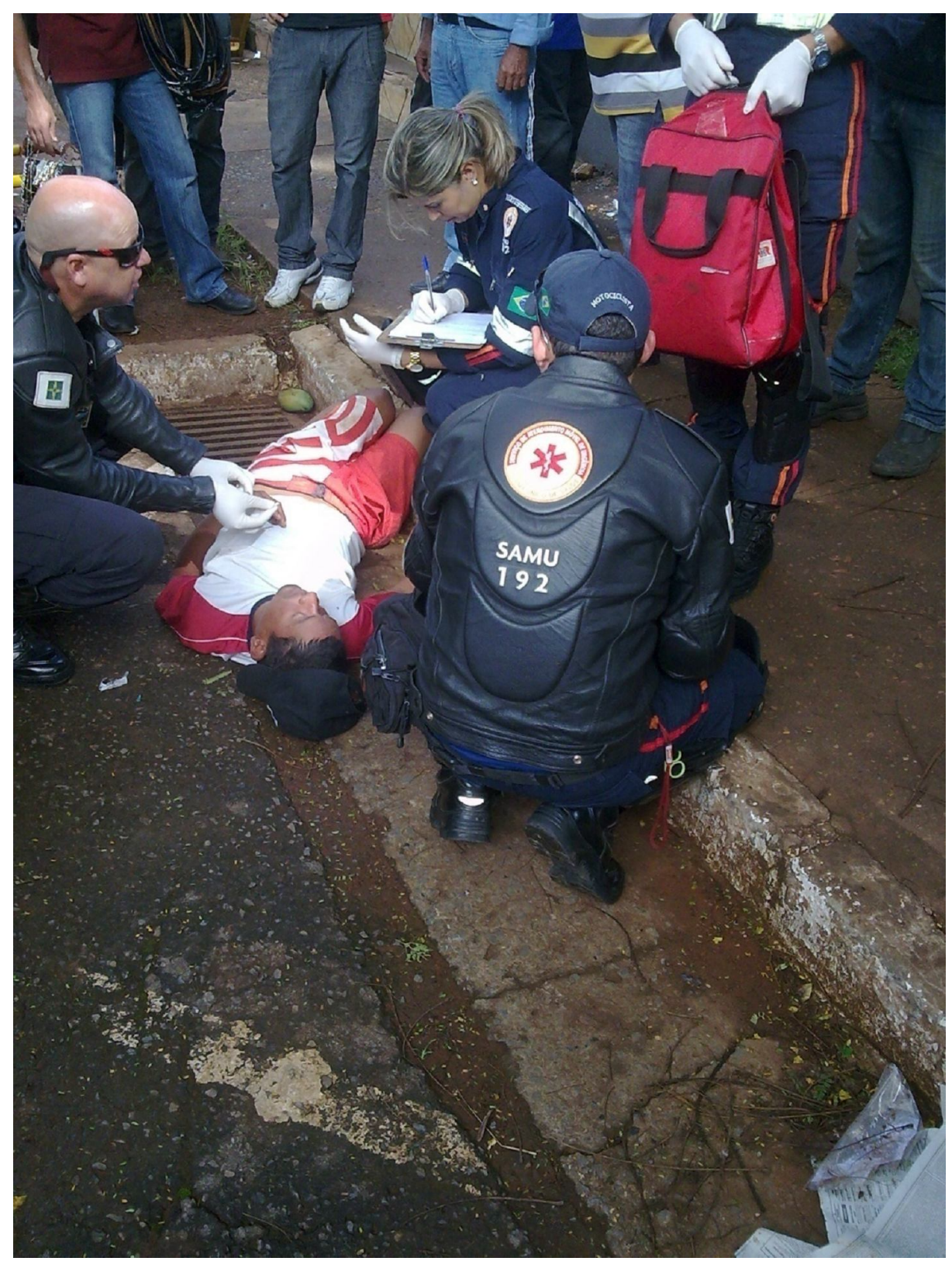




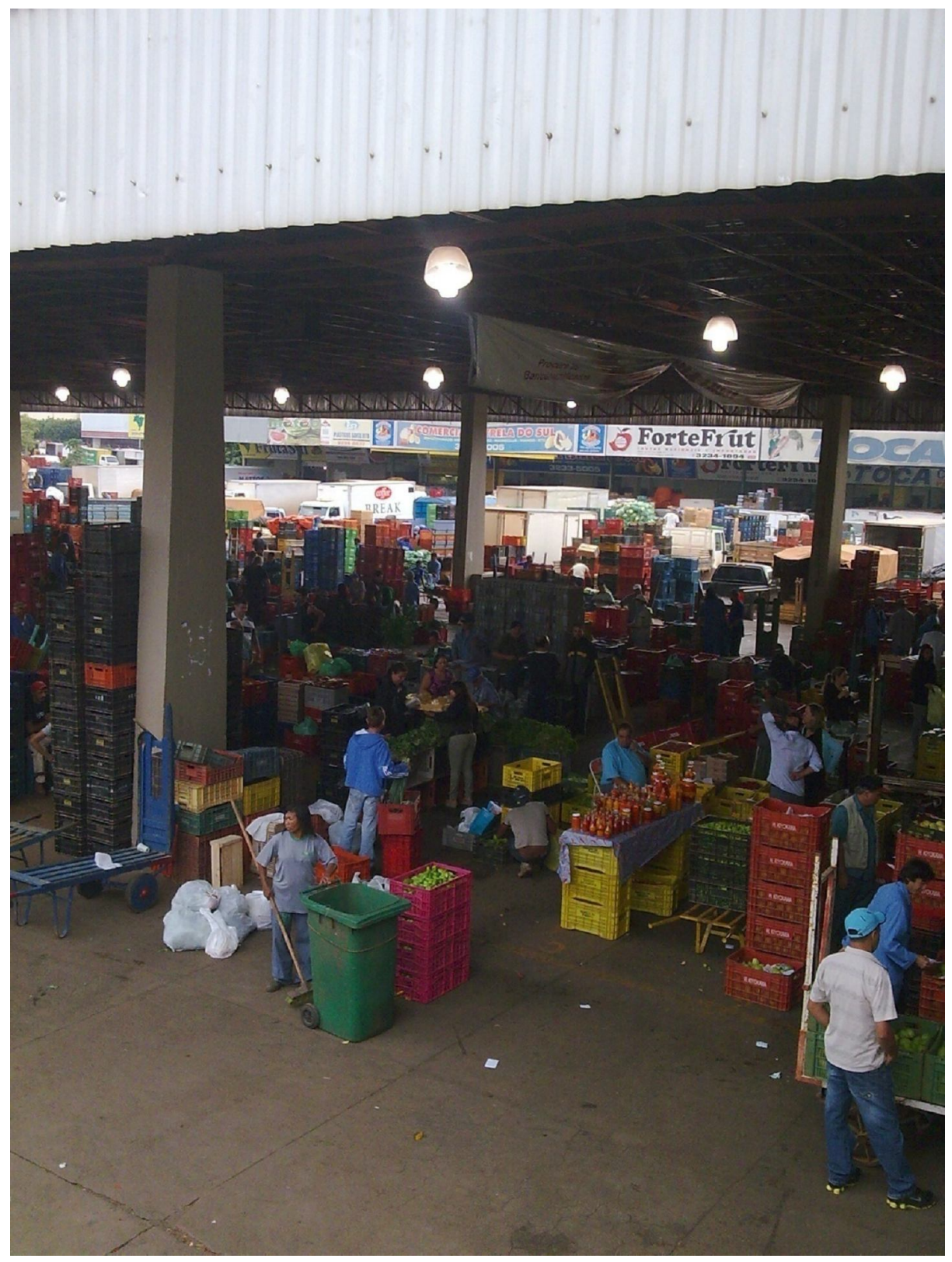

Figura 5. DIA DE VAREJÃO

Outro aspecto que merece consideração é a segurança. A bem da verdade, não tem havido maiores problemas de crimes nos espaços da Ceasa - DF, a não ser pequenos furtos de gêneros e algumas denúncias de que algumas pessoas consomem drogas nas áreas próximas aos pavilhões. Entretanto, nada garante que problemas maiores não venham acontecer; portanto, necessária se faz a presença de Policiais Militares armados e uniformizados, nos dias de feira, bem como a instalação de um circuito 
fechado de TV, de forma progressiva, até o recobrimento completo das áreas de monitoramento.

Por outro lado, há amplos indicadores que a Ceasa está no rumo certo, pois aspectos que eram deficientes foram dirimidos ou está em andamento sua resolução. $\mathrm{Na}$ administração atual nota-se $\mathrm{O}$ compartilhamento de uma política de reconstrução e desenvolvimento sustentável do sistema CEASA/DF.

Para mostrar o desenvolvimento iniciado com a retomada da governança do complexo administrativo da entidade que se achava em poder de uma Organização Social, detentora do contrato $n^{\circ}$ 001/2009, que the outorgava a gestão da Ceasa-DF, a nova direção, sob a liderança do Sr. Júlio Menegotto, iniciou imediatamente os trabalhos.

Com o objetivo de modernizar o processo de compras de equipamentos e contratação de serviços, bem como proporcionar economia de custos e celeridade nas transações, foi instituído o pregão eletrônico. Em seguida realizou-se a compra de 80 containeres, para a coleta seletiva do lixo da Ceasa-DF.

A nova administração optou pela Gestão Compartilhada com a SEAPA/DF e a EMATER/DF, estendendo apoio às Feiras dos Produtores de Ceilândia, Planaltina, Braslândia e Vicente Pires. Em parceria com a SEAPA/DF, a mesma elaborou o Projeto Desperdício Zero, que pressupôs a formação do Banco de Alimentos, que beneficiará escolas públicas, hospitais, creches, penitenciárias e demais Entidades Sociais do DF.

Implementou a criação do Galpão do Produtor, no Núcleo Rural de Taquara, na região de Planaltina - DF, visando o beneficiamento e a agregação de valor dos produtos ali comercializados.

A Ceasa - DF está participando de articulações para a integração com o Mercosul. Outras iniciativas, como a Ampliação da Pedra do produtor, na Ceasa- DF e A criação do dia da Sacola Cheia, que é uma promoção em que os produtores disponibilizam seus produtos, durante as feiras do varejão, a preços menores que os de mercado, com a finalidade de incentivar o consumo de hortaliças. 
Vale destacar que esta promoção deverá estender-se a todas as feiras dos produtores, a exemplo de Planaltina, que já a realizou em articulação com a Ceasa- DF.

Estas últimas iniciativas revelam a disposição de tornar efetivo o modelo de gestão alinhada com os pressupostos da qualidade. 


\section{ANÁLISE E INTERPRETAÇÃo DE DADOS}

\section{ENTREVISTA COM OS PERMISSIONÁRIOS}

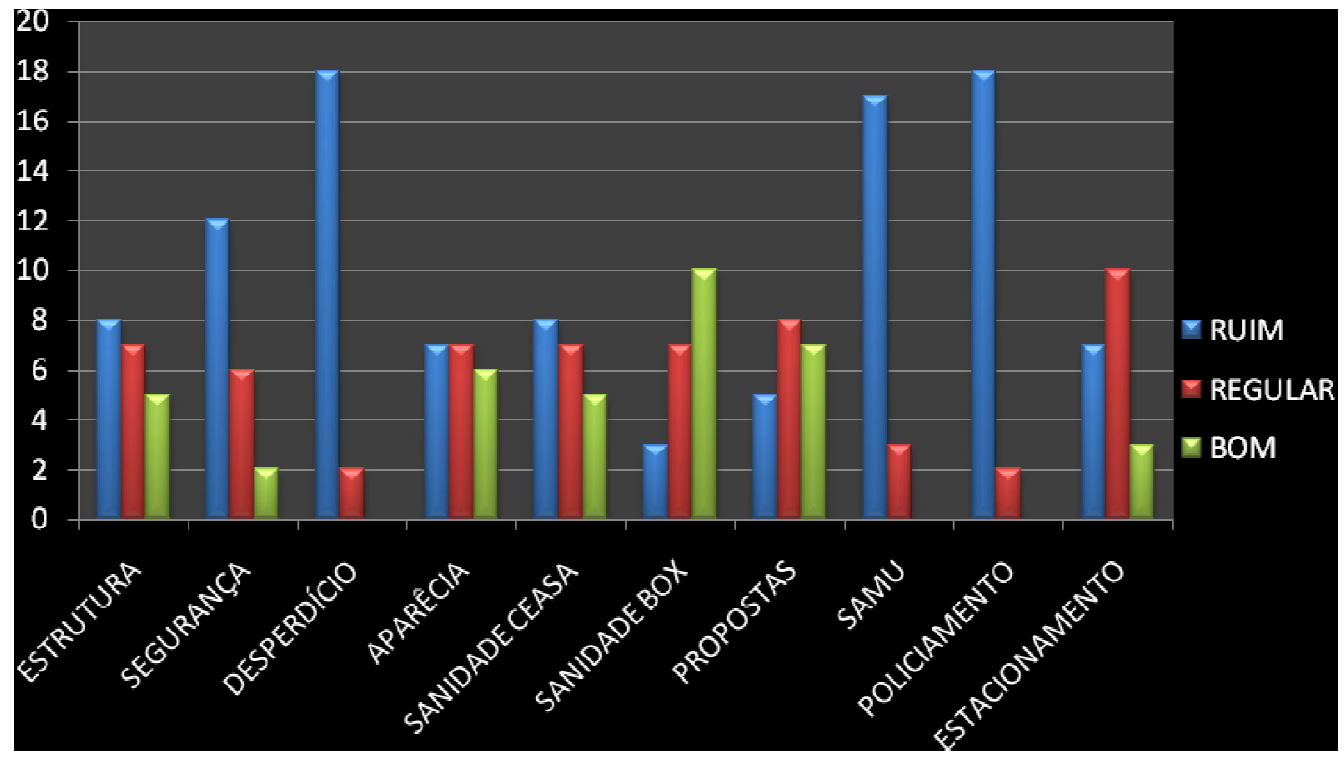

ENTREVISTA COM OS PRODUTORES

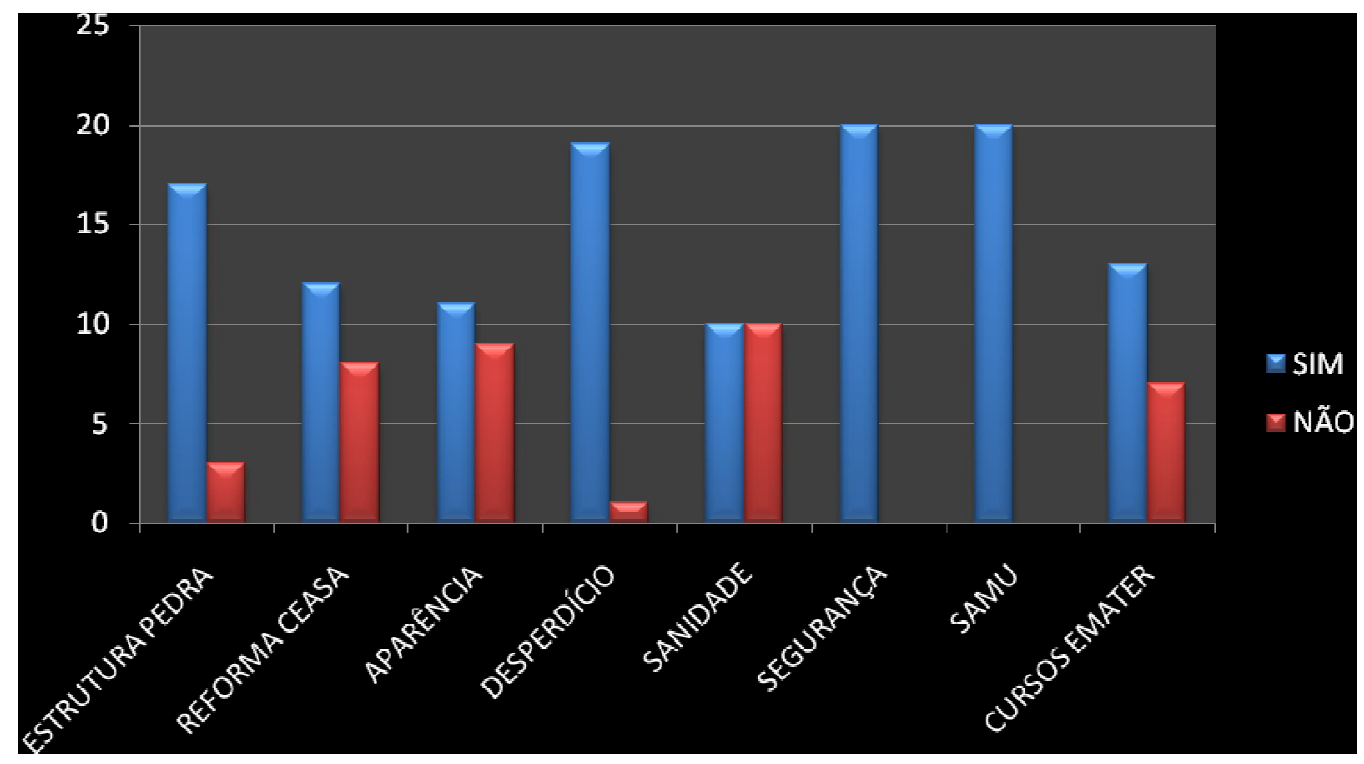




\section{ENTREVISTA COM OS COLABORADORES}

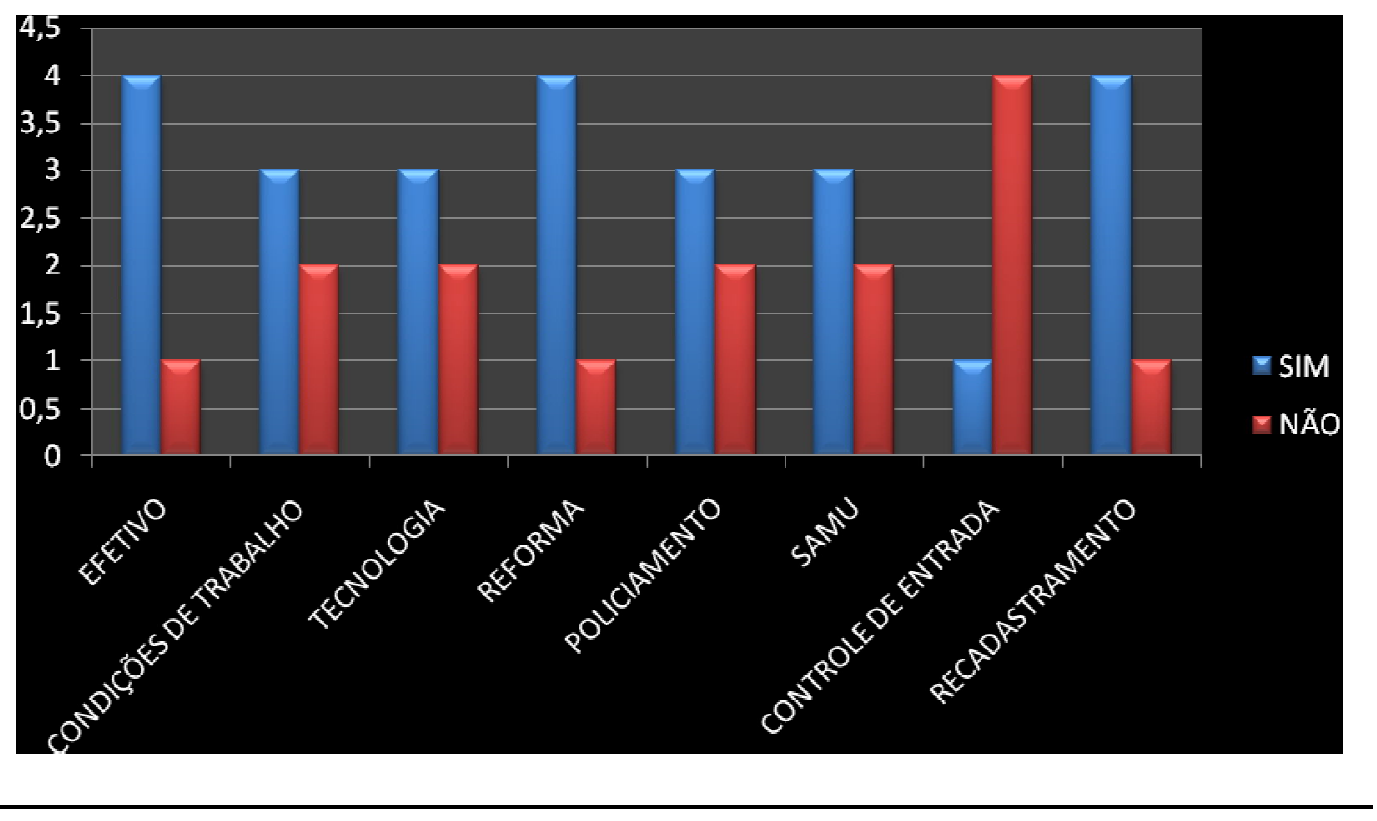




\section{SUGESTÕES}

Com base nas pesquisas feitas com permissionários, colaboradores e clientes, no exercício do estágio, sugerem-se as seguintes medidas:

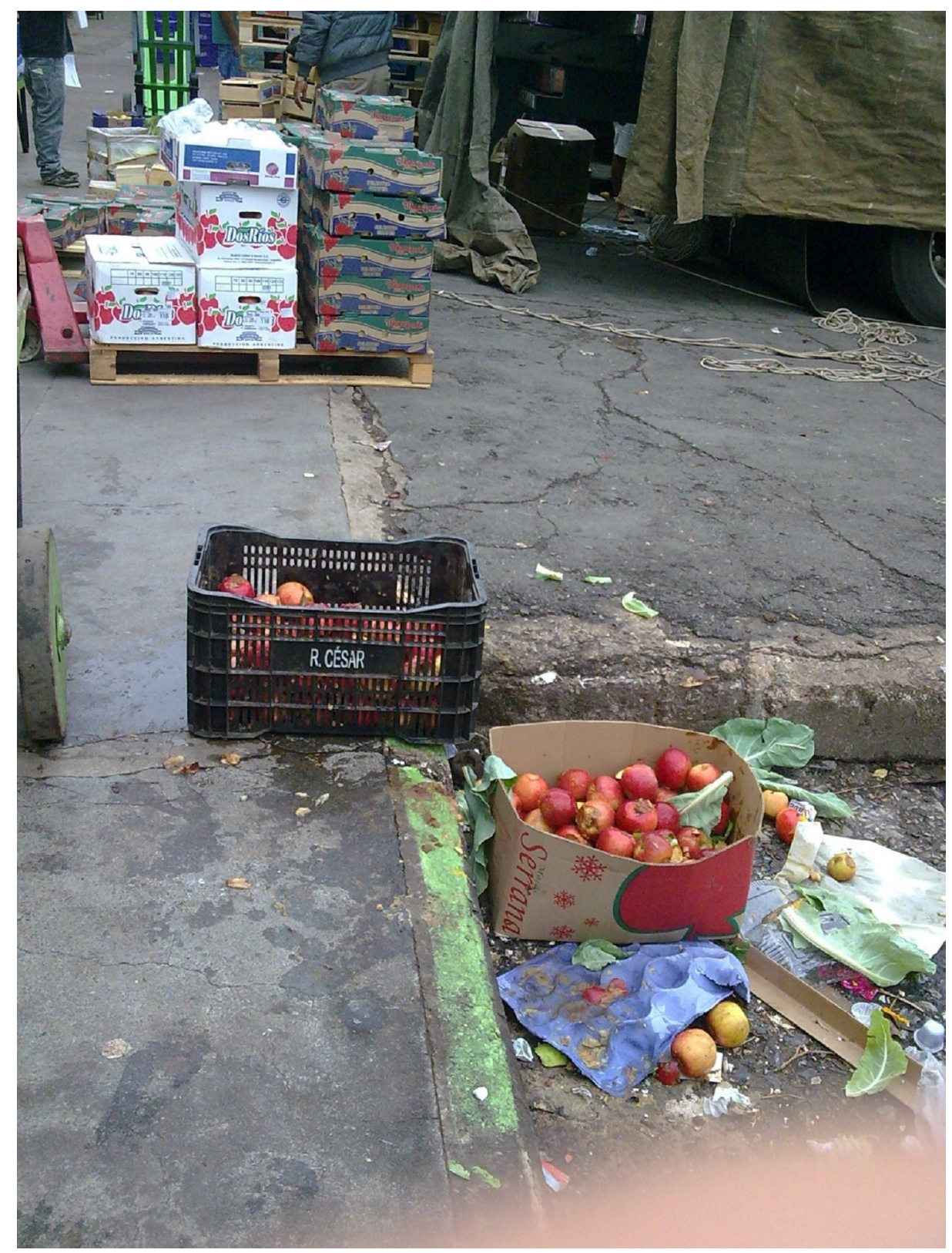

Figura 6. DESCARTE DO LIXO NA CALÇADA E NA RUA

1. Assinatura de Um Termo de Conduta entre a CEASA/DF e os Ministérios Públicos do Trabalho e do Meio-Ambiente, em que todos os permissionários serão obrigados a apresentarem um plano de gerenciamento de resíduos 
sólidos ao GDF, observados os princípios da redução, do reaproveitamento e da reciclagem dos resíduos, cuja separação para a coleta seletiva seja executada pelo próprio permissionário, ficando a coleta do lixo por conta da CEASA/DF;

2. Reativação ou Aperfeiçoamento do Programa Desperdício Zero e do Banco de Alimentos, para um melhor aproveitamento das frutas e verduras que são selecionadas para descarte, mas estão em condições plenas de uso.

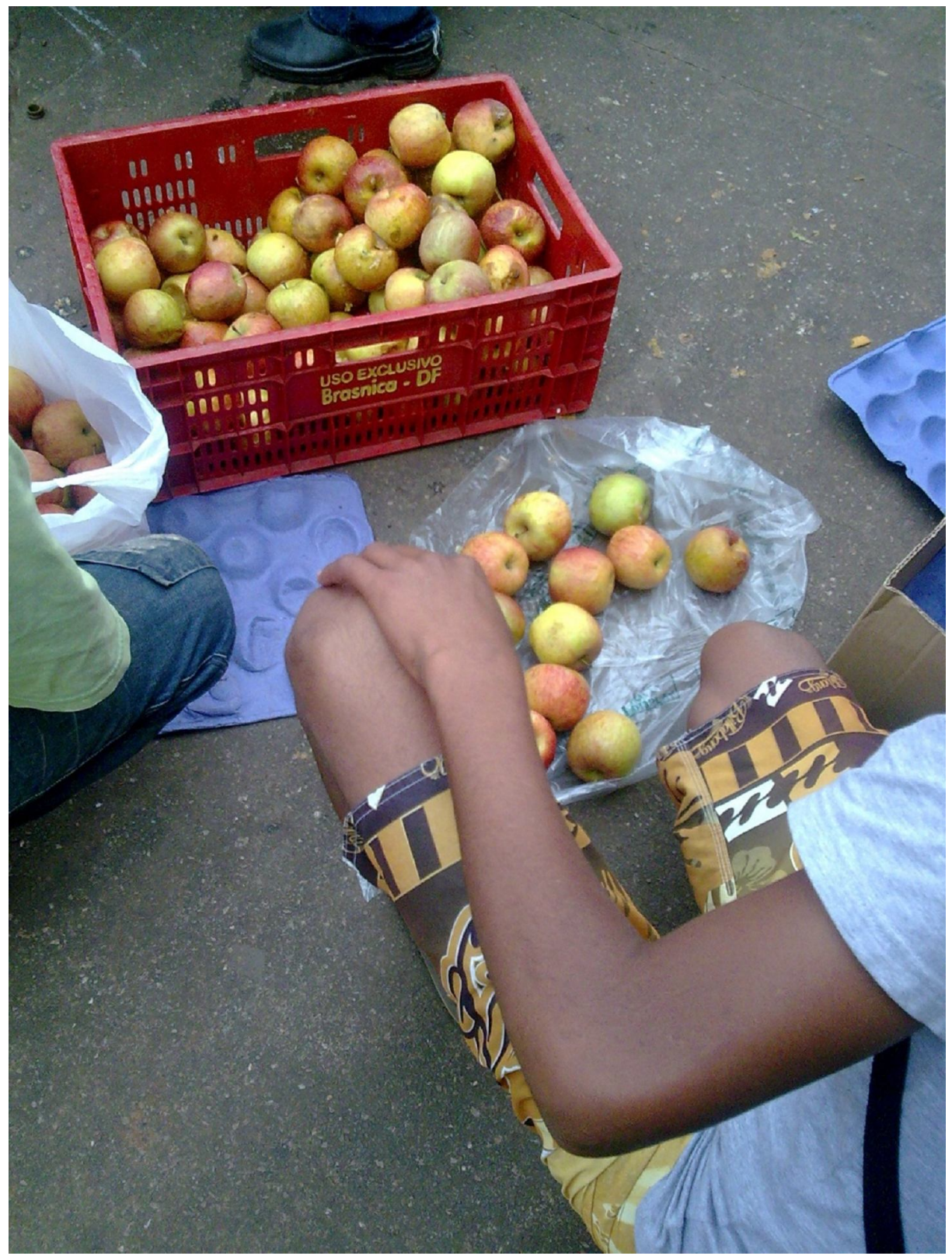

6. DESCARTE DO LIXO NA CALÇADA E NA RUA 
3. Promover, de forma efetiva, a sanidade e a higienização dos espaços de comercialização, sugerindo-se uma rotina, na qual o próprio produtor faça a limpeza do seu espaço alocado, colocando os detritos em baldes plásticos, com tampa, sendo estes recolhidos periodicamente pelos serventuários da limpeza. Vale lembrar que os impactos positivos que disto resulta poderão constar das palestras que a EMATER/DF vem ministrando aos produtores, no auditório da casa.

4. Obtenção de um efetivo mínimo de Policiais Militares uniformizados, especialmente nas adjacências do entreposto, nos dias de Atacadão e de Varejão;

5. Obtenção de Uma Unidade Médica de Socorro de urgência, mesmo que seja somente a presença de uma Ambulância com socorristas, ao menos nos dias das feiras de atacado e varejo;

6. Instalação de um Circuito Fechado de TV,para monitoramento em tempo integral, de forma progressiva e de acordo com as prioridades de uso, no que se refere à sua área de abrangência;

7. Implantação efetiva da Política de Sanidade e inocuidade dos Alimentos, com foco nas Resoluções n²16/2004 e 275/2002, da Anvisa, com seus anexos, que abrangem os assuntos referentes ao Regulamento Técnico de procedimentos Operacionais Padronizados-POP, aplicado aos Estabelecimentos Produtores/Industrializadores de Alimentos e todos os demais aspectos de higiene operacional, bem como o Manejo Integrado de Pragas e vetores Urbanos (problema recorrente na CEASA/DF). Isto poderá ser feito através de celebração de um convênio com o Ministério da Saúde (Anvisa) e ou/do MAPA; 
8. Estabelecer uma padronização nas bancas dos produtores que realizam a comercialização na pedra do produtor. Faz-se notar a heterogeneidade do layout, do estado de conservação, sem contar que, pelo fato de não serem devidamente revestidas, as bancas absorvem os substratos das frutas e verduras nelas expostas, ocasionando a formação de microorganismos patogênicos, capazes de realizar a contaminação direta e até mesmo a contaminação cruzada, quando se dar o contato daqueles produtos com outros, manuseados pelo comprador. 


\section{CONCLUSÕES}

Ao término dos trabalhos realizados nestes três últimos meses, junto a Ceasa-DF, percebe-se que o estágio foi de capital importância para a formação acadêmica. Levando-se em consideração que se constitui na mais adequada oportunidade de confrontação da teoria com a prática, pelo exercício das técnicas de gestão, auferidas no aprendizado do Curso de Gestão do Agronegócio, da Universidade de Brasília.

No decorrer do tempo em que foram vivenciadas as atividades do cotidiano da organização, conclui-se que se fazem necessárias as mudanças sugeridas, em virtude da pertinência do alinhamento das iniciativas com os pressupostos da Gestão da Qualidade, que, de certa forma, senão sobremaneira, aplica-se à qualquer empresa, sobretudo, aquelas que lidam com a comercialização.

Espera-se que todo o trabalho que foi desenvolvido neste estágio tenha sido de real proveito para a Ceasa-DF e que se faça pelo menos o exame da oportunidade e da pertinência das proposições constantes deste trabalho. 


\section{REFERÊNCIAS}

DEMING, W. Edward. Out of the crisis . Boston, MA: Press, 1986.

JURAN, J.M. Juran. Planejamento para a qualidade. São Paulo: Pioneira, 1990.

JURAN, J.M. Juran. A qualidade desde o Projeto. Novos Passos para o Planejamento da Qualidade em Produtos e Serviços. São Paulo: Pioneira, 1992.

CROSBY, Philip B. Qualidade Falada a Sério. São Paulo: Mc Graw-Hill do Brasil, 1990.201p.

CROSBY, Philip B. Qualidade é investimento. Rio de Janeiro: José Olympio, 1994.

CARDOSO, Diga Regina. Foco na Qualidade Total no Conceito do Produto Ampliado. Florianópolis; Tese de Doutorado - EPS - UFSC, 1995.

BROWM, Mark Grahan. O Sistema Baldrige da Qualidade. São Paulo: Makron Books, 1995.

KOTLER, Philip. Administração de Marketig: Análise, Planejamento, Implementação e Controle. 5. Ed. São Paulo: Atlas, 1998.

PALADINI, Edson Pacheco. Qualidade Total na Prática. Implantação e Avaliação de Sistema de Qualidade Total. 2ed. São Paulo: Atlas, 1997. PORTER, Michel E. Vantagem Competitiva - São Paulo, Campus, 1989. 
ANEXOS 